\title{
Procedures for listing loci and alleles of ruminants: 1991 proposals
}

E Andresen ${ }^{1}$, T Broad ${ }^{2}$, L Di Stasio ${ }^{3}$, CHS Dolling ${ }^{4}$, D Hill $^{5}$, K Huston ${ }^{6}$, B Larsen $^{7}$, JJ Lauvergne ${ }^{8 *}$, H Levéziel ${ }^{9}$, $\mathrm{X}$ Malher ${ }^{10}, \mathrm{P}_{\text {Millar }}{ }^{11}$, AL Rae ${ }^{12}$, C Renieri ${ }^{13}$, EM Tucker ${ }^{14}$

${ }^{1}$ Division of Animal Genetics, Department of Animal Science and Health, Bülowsvej 13, 1870 Frederiksberg $C$, Denmark;

${ }^{2}$ DSIR Grassland, Palmerston North, New Zealand;

${ }^{3}$ Dipartimento di Scienze Zootechnice, Via Genova, 6, 10126 Turin, Italy;

${ }^{4}$ Box 74, Mc Laren Vale, SA 5171, Australia;

${ }^{5}$ University of Otago, Department of Biochemistry, Box 56, Dunedin, New Zealand;

61689 Arthur Drive, Wooster, OH 44691 , USA;

7 National Institute of Animal Science, Department of Animal Physiology and Biochemistry, PO Box 39, 8830 Tjele, Denmark;

${ }^{8}$ Laboratoire de Génétique Factorielle, Département de Génétique Animale de l'INRA, CRJ, 78 352 Jouy-en-Josas, Cédex;

${ }^{9}$ Laboratoire de Génétique Biochimique, Département de Génétique Animale de l'INRA, CRJ, 78 352 Jouy-en-Josas, Cédex;

${ }^{10}$ École Nationale Vétérinaire de Nantes, Département des Productions Animales, BP 527, 44026 Nantes Cédex, France;

11 Britbred Ltd, 12A Riselaw Crescent, Edinburgh, EHIO 6HL, UK;

12 16, Wallace Place, Palmerston North, New Zealand;

13 Istituto di Produzioni Animali, Via San Constanzo 4, 06100 Perugia, Italy;

${ }^{14}$ AFRC, Institute of Physiology and Genetics Research, Babraham, Cambridge CB2 4AT, UK

(Received 27 February 1992; accepted 31 March 1992)

Summary - The following procedures for listing loci in ruminants were proposed at the 1991 1st Workshop on Genetic Nomenclature of Farm Ruminants organised by COGNOSAG (Committee on Genetic Nomenclature of Sheep and Goats): identification of locus, genomic location, gene effect classification (24 entries), summary of alleles and, for each allele, after identification, phenotypic effect, inheritance and breeds implied. This

* Correspondence and reprints 
set of procedures is intended for the first edition of the MIS, MIG and MIC catalogues (mendelian inheritance in sheep, goats and cattle, respectively) and is a basis for future data banking.

ruminants / loci / listing procedures / nomenclature

Résumé - Procédures de listage des loci et allèles des ruminants 1991. Au cours du premier Atelier de Nomenclature Génétique des Ruminants de Ferme organisé par le COGOVICA (Comité de Nomenclature Génétique des Ovins et Caprins) en 1991, les procédures suivantes de listage des loci chez les Ruminants ont été proposées: identification du locus, localisation sur le génome, effet du gène (24 entrées), tableau des allèles et, pour chaque allèle, outre l'identification, l'effet phénotypique, l'hérédité et les races concernées. Conçue pour être utilisée dans la première édition des catalogues $M I S, M I G$ et $M I C$ (Mendelian Inheritance in Sheep, Goats and Cattle resp), cette grille peut servir de base pour une future banque de données.

ruminants / loci / procédures de listage / nomenclature

\section{INTRODUCTION}

The definition of guidelines for gene nomenclature of sheep and goats was prepared during COGNOSAG Workshops (Committee on Genetic Nomenclature of Sheep and Goats) in 1987 and 1989 (Alexieva et al, 1989a, 1990). At the 1991 Workshop, entitled First Workshop on Genetic Nomenclature of Farm Ruminants, these guidelines were reviewed so that they would be suitable for all ruminants (Andresen et al, 1991).

Besides these guidelines COGNOSAG started to elaborate the general procedure of listing loci and alleles of sheep and goats during the 1987 Workshop (Alexieva et al, 1989b). This document was revised almost without change during the Workshop at Eugene (Oregon) in 1989, and, at the above-mentioned 1991 Workshop, these procedures were again reviewed and are given in the present article. The purpose is to make them suitable for all ruminants in order to prepare a first edition of MIS, MIG and MIC catalogues (mendelian inheritance in sheep, goats and cattle respectively) and also to be used in future data banking.

\section{OBJECTIVES}

The objectives are to use the guidelines for gene nomenclature elaborated during the above-quoted 1991 Workshop (Andresen et al, 1991) to produce a list of loci and alleles for cattle, sheep and goats, and to assess the contribution made by each reference to knowledge of the inheritance of the allele.

The list and assessment are such that they can be fully checked by other workers, and can be added to or amended as necessary. 


\section{CATEGORIES OF LOCI AND HEADINGS}

Within each of the species - cattle, sheep and goats - loci are classified into 4 categories, namely:

1. Coat colour

2. Visible traits other than coat colour

3. Blood, milk and other body fluids

4. Other genetic systems (eg molecular markers)

Loci and alleles are listed within each of the above categories. The information available on each locus and on each allele should be given under the following basic set of headings:

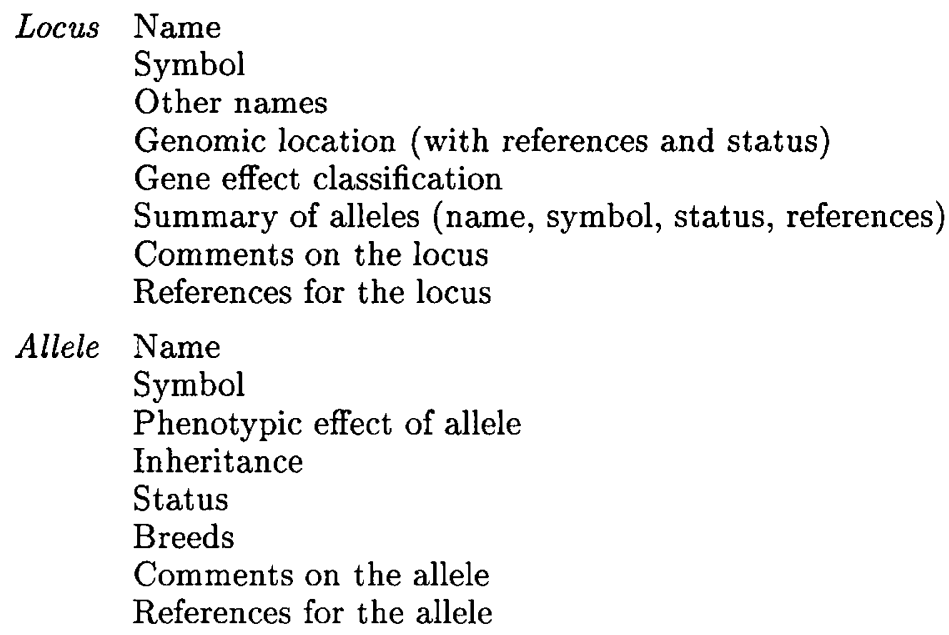

Then, as an option, at the end of the listing of all loci and alleles in a category: Bibliography.

\section{LOCUS DESCRIPTION (DETAILS)}

\section{Name, symbol, other names}

Names and symbols are defined as set out in the COGNOSAG Guidelines for Gene Nomenclature in Ruminants 1991 (Andresen et al, 1991).

The "other names" for loci include those which have been used in the literature other than the names designated by COGNOSAG.

Geographic terms are used to describe loci or alleles found in different parts of the world if:

- alleles with similar effects have been identified in different regions;

- tests for allelism have not been carried out; or 
- additional description is needed to prevent confusion in the term used to designate locus or allele.

The loci are considered as being separate until tests for allelism have been carried out.

\section{Genomic location}

This will be specified by selecting one of the following descriptors:

i) undefined, where the genomic location has not been reported;

ii) sex chromosomes or autosome, when there is evidence implicating either the $\mathrm{X} / \mathrm{Y}$ chromosomes or the autosomes but insufficient evidence to go beyond this;

iii) the chromosome number, arm or region, as defined by ISCNDA 1989 rules (1990) and/or earlier reports of the Committee for Standardisation of the Karyotypes of Domestic Animals (Reading Conference, 1980; Long, 1985). If only chromosome number but no further information on the regional localisation of a locus is known, this will be indicated as eg "Chr 7" or "Chr 8". Designating chromosome arms as either " $p$ " or " $q$ " will only be appropriate for the sheep autosomes, chromosome numbers $1-3$, the cattle $\mathrm{X}$-chromosome and the $\mathrm{Y}$-chromosome in all ruminants;

iv) the syntenic group will be designated by the symbol " $U$ " followed by an Arabic number, eg U1, U2, etc... Such designations will be most frequently made from studies involving somatic cell hybrids in which the identification of ruminants chromosomes retained by the hybrid cells has not been reported;

v) the linkage group will be designated by the symbol "LG" followed by an Arabic number, eg LG1, LG2, etc...; or,

vi) mitochondrial, where it is known that the locus is not located on the nuclear genome, but is present on the mitochondrial genome.

In most cases, it will be sufficient to select only one of those descriptors. However, there may be instances in which it is informative to specify 2 such descriptors, eg linkage groups, as well as the chromosome number.

Reference: a short reference comprising the name(s) of the authors and year will be given to support the genomic location of each locus.

Status: $\mathrm{P}$ or C. The "P" is to be allocated when there is only a single report of the location of a locus indicating that its location is "provisional". The " $\mathrm{C}$ " will be awarded when the location of a locus has been "confirmed".

\section{Gene effect classification}

Each locus is classified into one or more of the following classes:

1. Coat colour

2. Skin, fibres, hooves and horns and function

3. Skeletal system (including legs and tail) and function (including locomotion)

4. Appendages (including outer ears and wattles)

5. Nervous system (including brain, inner ear and eye) and function

6. Endocrine system (including dwarfism and obesity) and function 
7. Reproductive system (including fertility, gametes, zygotes, embryos and fetuses) and function

8. Circulatory system and function

9. Digestive system (including metabolism) and function

10. Muscle and function

11. Urinary system and function

12. Respiratory system and function

13. Mammary glands and lactation

14. Lethal, sublethal and subvital factors

15. Plasma enzymes

16. Plasma proteins other than enzymes

17. Erythrocyte enzymes

18. Erythrocyte proteins and transport systems other than enzymes

19. Erythrocyte antigens

20. Lymphocyte antigens

21. Milk proteins

22. Leucocyte enzymes

23. Leucocyte proteins other than enzymes

24. Resistance to assault

Disease

Toxins

Other

25. DNA sequences

\section{Summary of alleles (table)}

Name and symbol: the names and symbol are given as set out in the COGNOSAG Guidelines for Gene Nomenclature in Ruminants 1991 (Andresen et al, 1991). The alleles are listed in order of dominance, where known, the dominant allele being at the top.

Status: the evidence presented for each allele is assessed as follows, unless otherwise indicated in the introduction to a category listing:

- the evidence is such that the existence of the allele as being the cause of the effect is established beyond reasonable doubt. Segregation data which demonstrate this must be given. Evidence for the allele is unequivocal;

- the evidence is such that the allele is most probably the cause of the effect, but the possibility of other causes has not been reasonably excluded. Reports in this category would include those with extensive population studies or those with segregation data consistent with the existence of the allele, but for which the evidence is not unequivocal.

- the existence of an allele is postulated to explain the phenotype described: little or no evidence is presented by the author. 
References (in the table): the references for alleles are presented with the name of the author and year.

\section{Comments on the locus}

Comments may include historical definition of the effects of the locus or of the breeds which express the locus, and descriptions of cattle, sheep and goats with different genetic backgrounds. The nature of the evidence for the existence of the locus may be discussed. Homology of the locus with loci in other species, where known, is indicated.

\section{References for the locus}

References for the locus may be listed here or in a bibliography at the end of the category. They are given in alphabetical order of the name of the first author, and are not numbered.

All references for any category should be either in this format:

Adalsteinsson S, Basrur PK (1984) Inheritance of spina bifida in Icelandic lambs. $J$ Hered $75,378-382$

or in this format:

Adalsteinsson S, Basrur PK (1984) J Hered 75, 378-382

\section{ALLELE DESCRIPTION (DETAILS)}

\section{Phenotypic effect}

A brief description is given of the effects of the allele. The effects are those observed in the genetic background of the breed or strain of cattle, sheep or goats with which the authors worked, or on the wild type. The effects of the allele are described from the phenotypes of animals homozygous for the allele in question whenever possible.

\section{Inheritance}

Comments are made on the pattern of inheritance - possibly including some of the following terms:

- pleiotropy, polygenic (quantitative), genetic background, epistasis;

- incomplete penetrance, variable expressivity, threshold character;

- dominant, co-dominant, recessive.

Status: an assessment of the evidence presented for each allele is made as described above.

\section{Breeds}

The breeds mentioned in the references quoted for each allele are given. As a precaution against unwarranted extrapolation or inference, breeds not quoted in references are not listed. 


\section{Comments}

Comments may include the historical definition of the effects of the allele in the breeds which carry the allele, and descriptions of cattle, sheep and goats with different genetic background. The nature of the evidence for the existence of the allele may be discussed.

\section{References for the allele}

References for the allele may be listed here or in a bibliography at the end of the category. They should all be in one of the forms exemplified above (see References for the locus).

\section{REFERENCES}

Alexieva SA, Aliev G, Bourzat D, Denis B, Dolling CHS, Lauvergne JJ, Lundie RS, Millar P, Rachovski ML, Rae AL, Renieri C, Sponenberg DP, Tucker EM (1990) Gene nomenclature in sheep and goats, 1989, In: Loci for Coat Colour in Sheep and Coats (JJ Lauvergne, ed) COGNOSAG, Clamart

Alexieva SA, Denis B, Dolling CHS, Lauvergne JJ, Lundie RS, Millar P, Rae AL, Renieri C, Sponenberg DP, Tucker EM (1989) Gene nomenclature in sheep and goats 1987. In: Proc COGNOSAG Workshop 1987 (JJ Lauvergne, ed) Bureau Ressources Génétiques, Paris, 17-21

Alexieva SA, Denis B, Dolling CHS, Lauvergne JJ, Lundie RS, Millar P, Rae AL, Renieri C, Sponenberg DP, Tucker EM (1989b) General procedures for listing loci and alleles of sheep and goats 1987. In: Proc COGNOSAG Workshop 1987 (JJ Lauvergne, ed) Bureau Ressources Génétiques, Paris, 23-32

Andresen E, Broad T, Di Stasio L, Dolling CHS, Hill D, Huston K, Larsen B, Lauvergne JJ, Levéziel H, Malher X, Millar P, Rae AL, Renieri C, Tucker EM (1991) Guidelines for gene nomenclature in ruminants 1991. Genet Sel Evol 23, 461-466

ISAG Nomenclature Standardisation Workshop (1985) Anim Blood Groups Biochem Genet 16, 249-252

ISCNDA (1989, 1990) International System for Cytogenetic Nomenclature of Domestic Animals (D Di Bernardino, H Hayes, R Fries, S Long, eds) Cytogenet Cell Genet 53, 65-79

Long S (1985) Standard nomenclature for the G-band karyotype of the domestic sheep (Ovis aries). Hereditas 103, 165-170

Reading Conference (1980) Proc Ist Int Conf Standard Banded Karyotypes Domest Anim, Reading, England, 1976 (EC Ford, DL Pollock, I Gustavsson, eds) Hereditas 92, 145-162 